\title{
The WHO-Destined to Fail?: Political Cooperation and the COVID-19 PANDEMIC
}

\author{
By Eyal Benvenisti
}

\section{ABSTRACT}

In this Essay, I argue that the World Health Organization (WHO) has not been equipped with the necessary authority to adequately fulfill its mission. The WHO was built on the mistaken assumption that attaining adequate global health is a matter of high-level coordination. However, the challenge of global health governance is, crucially, also one of complex political cooperation. I distinguish between different types of cooperation problems faced by the WHO and explain why achieving global health calls for intrusive powers by a governing authority - powers that the WHO does not enjoy.

\section{INTRODUCTION}

The criticisms leveled at the World Health Organization (WHO) since the onset of the COVID-19 global pandemic in early 2020 are fundamentally misguided. Admittedly, the organization reacted slowly to information about an outbreak of coronavirus in China, and offered imprudent advice-exhorting states to avoid travel bans, even after China had imposed a lockdown in Wuhan. ${ }^{1}$ But these errors of judgment betray a more fundamental flaw: the very design of the WHO is not fit for the challenges it faces. The organization was designed on an assumption that the improvement of global health was the shared goal of all nations and that fighting disease was an effort to which all are committed.

Given this assumption, the underlying premise of the visionaries behind the $\mathrm{WHO}$ was that the primary challenge in the pursuit of global health was a matter of expert coordination. A coordination problem requires a collective decision on which course to take, which expert theory to follow, or which standard to adopt. Once agreed, everybody shares the incentive to follow that standard. Hence, the founding fathers of the WHO Constitution perceived it as a body that could represent humanity by taking a science-based approach—one that transcended politics. ${ }^{2}$

* Whewell Professor of International Law, University of Cambridge, CC Ng Fellow, Jesus College, Cambridge, Visiting Professor, The Hebrew University of Jerusalem.

${ }^{1}$ Wuhan Lockdown "Unprecedented," Shows Commitment to Contain Virus: WHO Representative in China, REUTERS (Jan. 23, 2020), at https://www.reuters.com/article/us-china-health-who-idUSKBN1ZM1G9. The WHO's updated advice did not include restrictions on international traffic. WHO, Updated WHO Advice For International Traffic in Relation to the Outbreak of the Novel Coronavirus 2019-nCoV, (Jan. 24, 2020), at https://www.who.int/news-room/articles-detail/updated-who-advice-for-international-traffic-in-relation-tothe-outbreak-of-the-novel-coronavirus-2019-ncov-24-jan.

${ }^{2}$ See notes 8, 24-25 and accompanying text infra. 
But the COVID-19 pandemic has vividly demonstrated that the underlying challenge of improving global health is not one of poor coordination among scientists, nor even one of lack of scientific cooperation, but a lack of political cooperation. The WHO's efforts to combat the pandemic have been plagued by competing economic, political, and social demands_conflicts that render coordination difficult and cooperation impossible. ${ }^{3}$ As in other global-scale cooperation problems-such as climate change-even if everybody knows what needs to be done, at least some have the incentive to "cheat." Fighting pandemics poses collective risks to human society, but some are more vulnerable than others, and the associated costs_of prevention and treatment, for instance-are not shared equally. Seeking to protect their citizens, states are primed to take defensive action, such as underreporting outbreaks or closing their borders preemptively. ${ }^{4}$ At the same time there are also domestic conflicts of interest, as powerful lobbies weigh in to steer national and global health policies in their favor. ${ }^{5}$

This Essay analyzes the type of challenges that global health management poses and demonstrates that the WHO was not designed to wield the tools necessary to meet them. To substantiate this claim, I offer a typology of international organizations (IOs), distinguishing between the two fundamental types of challenge they address: coordination and cooperation (Part II). I explain why each of these two challenges requires distinct organizational tools, and then apply these insights to the challenges posed by global health management. In Part III, I examine the design of the WHO and argue that it was never conceived to fulfill the crucial role of ensuring international political cooperation. The opportunity to endow it with tools to effectively manage pandemics, was passed on in 2005 during the drafting of the International Health Regulations (IHR). As a result of the limited authority granted by the IHR, the WHO is unable to effectively respond to pandemics. Part IV concludes.

\section{Global Health Management: Between Coordination and Cooperation}

\section{A. Coordination and Cooperation Distinguished}

IOs seek to resolve complex issues situated between two poles: coordination problems and cooperation problems. ${ }^{6}$ Coordination problems reflect the need to agree on certain rules, such as which metrics to use or what language to speak. While parties may have diverse preferences, they share the interest of searching for a common rule. Therefore, coordination problems, while potentially contentious about the contents of the rules, tend not to require monitoring and enforcement of the rules once they are adopted.

\footnotetext{
${ }^{3}$ On the distinction between coordination and cooperation, see Duncan Snidal, Coordination Versus Prisoners' Dilemma: Implications for International Cooperation and Regimes, 79 AM. POL. SCI. Rev. 923 (1985).

${ }^{4}$ Patrick Zylberman, Civilizing the State: Borders, Weak States and International Health in Modern Europe, in Medicine at the Border: Disease, Globalization and Security (Alison Bashford ed., 2007); Alison Bashford, Imperial Hygiene: A Critical History of Colonialism, Nationalism and Public Health 115-36 (2004) (on disease as a motivation for states to enhance control of borders).

${ }^{5}$ Rob Davis \& Jasper Jolly, Aviation Bosses Raise "Serious Concern" Over UK Quarantine Plans, GuARDIAN (May 11, 2020), at https://www.theguardian.com/business/2020/may/11/heathrow-calls-for-urgent-plan-to-restartmore-flights.

${ }^{6}$ On these two problems as two "polar" situations. See Snidal, supra note 3, at 937.
} 
The drafters of the WHO Constitution saw its task as managing global coordination to eradicate disease. Hence, they designed an institution that would promote knowledge about diseases and how to avoid them, through a set of rules based on medical expertise. ${ }^{7}$ In this foundational model, politics are sidelined.

But global health management presents not only technical coordination problems but also requires political cooperation. Cooperation problems are usually mired by the fact that despite common goals, it is strategically advantageous for every actor to "cheat." A state may be minded to pollute a shared lake while others treat their sewage, to subsidize its own industries while others open freely welcome imports, and so on. Hence, to facilitate cooperation, it is not enough to set the rules. Instead, it is crucial to set up enforcement mechanisms to ensure compliance.

The management of global health poses both types of problem. Health is a coordination game, because actors need to know what the health risks are and the correct ways to treat the disease in question. A global body can reduce health risks by identifying pathogens and disseminating information about the most effective ways to remedy them. It can also resolve coordination problems for those active within states, ${ }^{8}$ e.g., by providing useful information to civil society activists seeking to curb the inordinate political power of lobbies such as tobacco companies, or big pharma companies.?

But global health also poses a set of interstate cooperation problems, as states have different capabilities and vulnerabilities that shape their responses to health risks. These differences create externalities, as one state can impose risks on another: often, states conceal outbreaks to avoid becoming "the target of other states' costly [trade] barriers." 10 Furthermore, scarcity problems plague the attainment of global health goals particularly in times of pandemics as states may hoard medical equipment, profiteer off in-demand resources, and limit their export. As much as nations want other nations to get rid of their illicit weapons while clandestinely keeping stocks of their own, some states would wish their neighbors to eradicate domestic causes of diseases while they keep pushing their farmers to clear forests and get even closer to virus-bearing animals.

\section{B. Global Health Poses a Complex Set of Cooperation Problems}

In the context of global health, there are specific factors that shape states' incentive to cooperate at all. The extant literature on global cooperation emphasizes the following as being influential: the number of participants (whether a bilateral or multiparty game); their expectation that they will repeat their engagement indefinitely; and the quality of the information

${ }^{7}$ Marcos Cueto, Theodore M. Brown \& Elizabeth Fee, The World Health Organization: A History 32-33, 39-40 (2019); David Macfadyen, The Genealogy of WHO and UNICEF and the Intersecting Careers of Melville Mackenzie (1889-1972) and Ludwik Rajchman (1881-1965) (Sept. 2014) (unpublished M.D. dissertation, Glasgow University), at http://theses.gla.ac.uk/5625.

${ }^{8}$ Beth A. Simmons, Mobilizing for Human Rights: International Law in Domestic Politics 125-48 (2012)

9 Tatiana Andia \& Nitsan Chorev, Making Knowledge Legitimate: Transnational Advocacy Networks' Campaigns Against Tobacco, Infant Formula And Pharmaceuticals, 17 GLOB. Networks 255 (2017).

${ }^{10}$ Catherine Z. Worsnop, Concealing Disease: Trade and Travel Barriers and the Timeliness of Outbreak Reporting, 20 Int'l Stud. Perspec. 344, 345 (2019). 
they have about the performance of their partners. ${ }^{11}$ Mancur Olson also emphasized relative power within communities as a factor that can encourage or hinder the possibility of overcoming collective action problems, as even just a few out of several actors_-provided they are sufficiently powerful - could unilaterally bear the collective burden of obtaining the public good. ${ }^{12}$ This literature has been invoked by international relations theorists to explain the benefits of IOs and to indicate which tools they should be equipped with to ensure their effectiveness. $^{13}$

Beyond the number of parties, the information to which they have access, and their relative capabilities, there are additional antecedent factors that help predict successful cooperation: (1) scope (whether single-issue or multi-issue); (2) frequency of iterations; and (3) relative vulnerability of the parties. As I briefly outline here, in the context of global health, these factors predict enormous challenges for cooperation.

(1) Scope: Single-issue cooperation involves one shared challenge that poses a collective action problem, such as the management of a specific stock of fish (e.g., Bluefin tuna ${ }^{14}$ or whales ${ }^{15}$ ) or weapons (anti-personnel landmines ${ }^{16}$ or chemical weapons ${ }^{17}$ ), as opposed to topics that interface with several other aspects of human activity (such as freshwater, which impacts demand on land, economic development, human rights, tourism, and so on). Elinor Ostrom has shown that a single issue to which only a few parties have access (e.g., certain fisheries or oil) can yield robust cooperation between them. ${ }^{18}$

(2) Frequency: Since an iteration of exchanges that runs indefinitely is key to the evolution of cooperation, frequently iterated exchanges, such as during the 1916 trench warfare, are likely to yield stable cooperation, even spontaneously. But when the iterations are intermittent and infrequent, cooperation is less stable and actors must find ways for parties to signal their continuous commitment.

(3) Relative vulnerability: Equal vulnerability occurs in situations of perfect reciprocity, when all parties can effect an outcome or benefit or suffer from it equally, such as fighters in their trenches or riparian states sharing a lake. In contrast, in situations of unequal vulnerability, such as with respect to climate change, the inclination to cooperate will differ. Parties locked in a situation of relative vulnerability might succeed in identifying other areas where they have opposing vulnerabilities (such as pollution and transport along a shared river) and

${ }^{11}$ Thomas C. Schelling, Strategy of Conflict (1960); Russell Hardin, Collective Action (1982); Robert Axelrod, The Evolution of Cooperation (1984); Michael Taylor, The Possibility of CoOperation (1987).

${ }^{12}$ Mancur Olson, A Theory of Collective Action (1965).

${ }^{13}$ E.g., Robert O. Kehoane, International Institutions: Two Approaches, 32 InT'L STUD. Q. 379 (1988); Helen Milner, International Theories of Cooperation Among Nations: Strengths and Weaknesses, 44 WorLD POL. 466 (1992); Barbara Koremenos, Charles Lipson \& Duncan Snidal, The Rational Design of International Institutions, 55 InT'L Org. 761 (2001); Kenneth W. Abbott \& Duncan Snidal, Why States Act Through Formal International Organizations, 42 J. CONFLICT REs. 3 (1998).

${ }^{14}$ Convention for the Conservation of Southern Bluefin Tuna, May 10, 1993, 1819 UNTS 359.

${ }^{15}$ International Convention for the Regulation of Whaling, Dec. 2, 1946, 161 UNTS 72.

${ }^{16}$ Convention on the Prohibition of the Use, Stockpiling, Production and Transfer of Anti-personnel Mines and on Their Destruction, Sept. 18, 1997, 2056 UNTS 211.

${ }^{17}$ Convention on the Prohibition of the Development, Production, Stockpiling and Use of Chemical Weapons and on Their Destruction, Sept. 3, 1992, 1975 UNTS 45.

${ }^{18}$ Elinor Ostrom, Governing the Commons: The Evolution of Institutions for Collective Action (1990). 
thereby "enhance or create a zone of possible agreement," 19 but at the cost of increasing the complexity and interrelatedness of the issues the IO is required to address.

The greater the extent to which an issue is single-faceted, elicits frequent indefinite iterations, and generates equal vulnerability among parties, the easier it is to ensure cooperation, perhaps through the simple promise of reciprocity and without the need for a global institution to ensure compliance. The more multifaceted, infrequent, and reflective of unequal vulnerabilities the issue is, the more challenging cooperation becomes. Global health management offers one of the more challenging cooperation problems along all these axes. A very large number of states face multiple forces at play (economic, social, cultural, and other considerations beyond the medical). The interaction, while indefinite, is infrequent because the rate of pandemics is rather low. ${ }^{20}$ Finally, states' vulnerabilities differ fundamentally: since the nineteenth century, most pathogens have originated in a few developing countries that externalized the risk on others, while the rest would close their borders, even preemptively, harming their trade partners in turn. These "upstream-downstream" relations have since become more complex, with states that are both sources of pathogens and exporters on which other states depend, and others who are "super-spreaders," given their dense economic networks. States also differ in their ability to adapt to health risks or their willingness to tolerate such risks.

This brief survey shows that IOs charged with managing global health must have the tools to overcome the most complex cooperation problems among mutually distrustful sovereigns. They must have independent and impartial global regulators with access to independent sources of information that they can share with all states. They must have norms and systems via which to share the burdens and benefits of global health goods, coupled with mechanisms to increase the frequency of iterations and to monitor and enforce compliance with such norms. Part III shows that the WHO was never designed to have these resources.

\section{The WHO: Between Expertise And Politics}

\section{A. The Promise of Expertise}

Among the WHO's functions are "to assist Governments, upon request, in strengthening health services; ... [and] to furnish appropriate technical assistance and, in emergencies, necessary aid upon the request or acceptance of Governments . ..." ${ }^{21}$ Its personnel are mainly technicians, "chosen from among persons most qualified by their technical competence in the field of health." 22 The scientific-technical aspect of the organization is also reflected in the authority of the World Health Assembly (the WHO's policy-setting body) to issue norms

\footnotetext{
${ }^{19}$ James K. Sebenius, Negotiation Arithmetic: Adding and Subtracting Issues and Parties, 37 INT'L Org. 281, 314 (1983); Koremenos, Lipson \& Snidal, supra note 13.

${ }^{20}$ Council of Economic Advisers, Executive Office of the President, Mitigating the Impact of Pandemic Influenza Through Vaccine Innovation (Sept. 2019), available at https://www.whitehouse.gov/wp-content/uploads/2019/ 09/Mitigating-the-Impact-of-Pandemic-Influenza-through-Vaccine-Innovation.pdf (the U.S. Council estimated "a 4 percent annual probability of pandemic influenza").

${ }^{21}$ Constitution of the World Health Organization (1948), Arts. $1 \& 2$

${ }^{22}$ Id. Art. 11.
} 
through a two-thirds majority of members acting and voting, binding all states parties without ratification unless they formally opt out. ${ }^{23}$

There is an optimistic premise here that, once expert science directs the way, all will follow its lead and adopt whatever measures the WHO deems necessary. The WHO was thus designed to respond only to the coordination of global health problems. Under this paradigm, there is no space for politics, and governments should simply be willing to cede authority for the global body to act without pre-approval. ${ }^{24} \mathrm{It}$ is for this reason that monitoring and enforcement tools are entirely absent from the WHO's repertoire.

For the industrialized West, such a body was probably deemed nonconstraining when it was created in the late 1940s. Although a multilateral body, this posed no concern for the United States and its allies. As one of its visionaries stated, "one could simply not expect the Great Powers to be overruled by a vote of less developed nations." 25 Science was seen as consonant with Western preferences; ${ }^{26}$ the WHO was expected to primarily address health standards in developing countries; ${ }^{27}$ and, as a U.S.-dominated body, it served (or domestically presented as serving) Western efforts to demonstrate their commitment to the global poor against Soviet intentions. ${ }^{28}$ The regulation of the possible (Western) responses to pandemics through trade and travel bans — which previously acted as the prime motivation for global health regimes ${ }^{29}$ — was diverted to the newly formed General Agreement on Tariffs and Trade (which acknowledged the right to balance trade against the protection of human life).$^{30}$ More profoundly, the WHO ensured the free flow of information from poorer countries (the source of the pathogens) to alert the West, which would respond by imposing costly trade and travel restrictions on the source state and developing vaccines that would be prohibitive for the South. ${ }^{31}$ The WHO, in this regard, served as a useful warning alarm to the rich states parties without committing them to share the risks and burdens of pandemics. Nevertheless, developing countries embraced the new body, and, indeed, Brazil and China

\footnotetext{
${ }^{23}$ Armin von Bogdandy \& Pedro Villareal, International Law on Pandemic Response: A First Stocktaking in Light of the Coronavirus Crisis (Max Planck Institute for Comparative Public Law \& International Law, Research Paper No. 2020-07, March 26, 2020), available at https://papers.ssrn.com/sol3/papers.cfm?abstract_id=3561650.

${ }^{24}$ According to the WHO Constitution, supra note 21, Art. 28(i), the Executive Board has authority "to take emergency measures within the functions and financial resources of the Organization to deal with events requiring immediate action."

${ }^{25}$ Macfadyen, supra note 7, at 223.

${ }^{26}$ Melville D. Mackenzie, Today's Global Frontiers in Public Health, 35 Am. J. Pub. Health 100, 104 (1945) ("In practice it is impossible to expect more developed countries to be overruled by the votes of nations less developed from a medical and social point of view."). Elizabeth Fee, Marcu Cueto \& Theodore M. Brown, At the Roots of the World Health Organization's Challenges: Politics and Regionalization, 106 AM. J. PuB. HeALth 1912 (2016) (in the early years, Europeans constituted the majority of the WHO staff, while the recruitment of a few medical experts from developing countries "was criticized for depleting precarious health systems of valuable individuals").

${ }^{27}$ Mackenzie, supra note 26, at 104-05.

${ }^{28}$ Fee, Cueto \& Brown, supra note 26 (citing U.S. politicians linking national security and the worldwide struggle against disease and poverty: “Disease and poverty must be fought [because they] 'feed communism”").

${ }^{29}$ Valeska Huber, The Unification of the Globe by Disease? The International Sanitary Conferences on Cholera, 1851-1894, 49 Hist. J. 453, 456, 471 (2006).

${ }^{30}$ David P. Fidler, From International Sanitary Conventions to Global Health Security: The New International Health Regulations, 4 CHINESE J. INT'L L. 325, 336-37 (2005).

${ }^{31}$ Until Indonesia demurred in 2006, leading to an arrangement with limited results. See Michelle F. Rourke, Access by Design, Benefits if Convenient: A Closer Look at the Pandemic Influenza Preparedness Framework's Standard Material Transfer Agreements, 97 Milbank Q. 91 (2019); Mark Eccleston-Turner, The Pandemic Influenza Preparedness Framework: A Viable Procurement Option for Developing States?, 17 MED. L. InT'L 227 (2017).
} 
tabled in 1945 the proposal for setting up an international health organization, ${ }^{32}$ because they saw it as their key to modernity. ${ }^{33}$ Perhaps it was this meeting of different interests that obscured the fact that global health management is something more complex than an apolitical coordination effort.

COVID-19 is not the first time that this vision was put to the test. Among earlier cases there is one that stands out - the SARS outbreak in 2002-2003-because it remains a marker of success for what the WHO can achieve when it expands its authority. It is to this case that we now turn.

\section{B. Activism During the SARS Pandemic: Functionalism Gone Ultra Vires?}

There was a rare moment in the life of the WHO when it sought to promote global cooperation. It was when the WHO responded swiftly and effectively in response to the SARS outbreak, it demonstrated what an independent, resourceful global body can achieve. ${ }^{34}$ The aftermath also showed the implications for states that prefer short-term gains and have no faith in the WHO. The organization was directed by a seasoned politician (Gro Harlem Brundtland, formerly Norway's prime minister) and by resourceful and committed medical experts operating in China, Hong Kong, and Vietnam. In a matter of weeks, overcoming lack of cooperation and even resistance by governments, the WHO obtained independent information and acted on it by issuing public advisories and drafting teams of experts into countries to ensure that they were following effective policies. It issued a global alert with recommendations and travel advisories. ${ }^{35}$ It resorted to public shaming of China and even issued an ultimatum to elicit its cooperation. ${ }^{36}$ The Washington Post aptly likened the WHO to "the natural if unelected leader of a crowded lifeboat, [that] gave orders that no one wanted to be the first to disobey." 37

Was the WHO acting within its powers? The general jurisprudence concerning powers of IOs, which celebrates "functionalism," would probably be supportive of such permissive interpretations of IO powers as "essential to the performance of [their] duties." 38 But at

32 Cueto, Brown \& FeE, supra note 7, at 37-38.

33 See Sunil Amrith, Decolonizing International Health: India and Southeast Asia, 1930-65, at 159 (2006); Randall M. Packard, Civilizing the State: Borders, Weak States and International Health in Modern Europe, in International Development and the Social Sciences 94, 96 (Roger Cooter \& John Pickstone eds., 1998).

34 This was not the only case of effective intervention. During 2003 it also publicly criticized Indonesia for refusing to cull flocks of infected birds, and the pressure led to compliance. MARK W. ZACHER \& Tania J. Keefe, The Politics of Global Health Governance: United by Contagion 60 (2008).

35 When Toronto was included in a Travel Advisory, on April 23, 2003, the Canadian government demurred and "following political representations at the highest level," Toronto was dropped six days later. Id. at 61.

${ }^{36}$ For the reaction of the WHO to the SARS pandemic, see DAVID P. FIDLER, SARS, Governance AND THE Globalization of Disease (2004). See also Sara E. Davies, Adam Kamradt-Scott \& Simon Rushton, Disease Diplomacy: International Norms and Global Health Security 43-73 (2015).

${ }^{37}$ David Brown, The SARS Triumph, and What It Promises, WASH. POST (July 20, 2003), at https://www.washingtonpost.com/archive/opinions/2003/07/20/the-sars-triumph-and-what-it-promises/b17713be-2ced-4963$8 \mathrm{db} 2-\mathrm{f} 5 \mathrm{fb} 46 \mathrm{f} 3956 \mathrm{~b}$.

${ }^{38}$ Reparation for Injuries Suffered in the Service of the United Nations, Advisory Opinion, 1949 ICJ Rep. 174, 183 (Apr. 11). See Adam Kamradt-Scott, The Evolving WHO: Implications for Global Health Security, 6 GlOB. PuB. HEALTH 801 (2011) (suggesting that WHO actions might have been covered by implied emergency powers for it to take all measures necessary to avert an impending global health threat). On functionalism generally, see Jan 
the time, even supporters of the WHO leadership noted that it acted beyond its mandate and "without deference to the sovereignty of affected states."39

\section{Reasserting Sovereignty: The IHR (2005)}

Initially, most member states were supportive of how the WHO had handled the SARS pandemic. However, a year later, when debating major revisions to the IHR (to extend the scope of the 1969 Regulations and develop a new legal framework for them), "governments had collectively agreed to impose new restrictions on the Director-General's autonomy." 40 This agreement reflected their inability to overcome a fundamental, intractable conflict: developed states wanted the WHO to have greater access to non-state-based information about impending health risks but limited authority to censure their protective measures; while developing countries insisted that the WHO remain dependent on information only they would provide, and demanded more accountability from states blocking trade. ${ }^{41}$ The outcome was an agreement to "reify member states' sovereignty." 42

The revised IHR thereby undercut the WHO's authority to offer a swift and resolute response to outbreaks. In a significant departure from the $2004 \mathrm{draft},{ }^{43}$ the IHR also undermined the WHO's very basic function of providing information to facilitate coordination. The WHO now has to consult with a source state before exercising its powers, ${ }^{44}$ and its freedom to obtain independent information from sources other than the affected state government is severely limited. ${ }^{45}$ Furthermore, the WHO may share such information with other states only after the source state refuses to collaborate and only "when justified by the magnitude of the public health risk." ${ }^{46}$ Crucially, the WHO has a legal duty to reveal to the source

Klabbers, The EJIL Foreword: The Transformation of International Organizations Law, 26 EUR. J. INT'L L. 9 (2015); Eyal Benvenisti, The Law of Global Governance (2014).

${ }^{39}$ FidLER, supra note 36, at 142.

40 Adam Kamradt-Scott, The International Health Regulations (2005): Strengthening Their Effective Implementation and Utilisation, 16 INT'L ORG. L. Rev. 242, 255-56 (2019). For a legal analysis of the IHR, see J. Benton Heath, Pandemics and Other Health Emergencies, in Oxford Handbook of International Law AND Global SECURITY (forthcoming 2020), available at https://ssrn.com/abstract=3574149. For generally supportive assessments of the IHR, see David P. Fidler \& Lawrence O. Gostin, The New International Health Regulations: An Historic Development for International Law and Public Health, 34 J. L., Medicine \& ETH. 85, 86 (2006) (referring to the IHR as "radically depart[ing] from the traditional approach . . . transform[ing] the international legal context in which states will exercise their public health sovereignty in the future . . ."). See also Stefania Negri, Communicable Disease Control, in Research Handbook on Global Health LaW 273-78 (Gian Luca Burci \& Brigit Toebes eds., 2018) ("landmark innovative instrument”).

${ }^{41}$ Christian Kreuder-Sonnen, Emergency Powers of International Organizations 162 (2019).

${ }^{42}$ Kamradt-Scott supra note 38, at 806.

43 WHO Intergovernmental Working Group on the Revision of the International Health Regulations, IGWG/IHR/Working Paper/12.2003 (Jan. 12, 2004), available at https:/www.who.int/csr/resources/ publications/IGWG_IHR_WP12_03-en.pdf (see also two subsequent meetings including summary reports of the regional consultations, at http://apps.who.int/gb/ghs/e). The verbatim records of the regional meetings and plenary sessions remain classified. KREUDER-SONNEN, supra note 41, at 164.

${ }^{44}$ International Health Regulations, Art. 12, May 23, 2005, 2509 UNTS 79 [hereinafter IHR] (the director general must consult with the Emergency Committee and with the source state before declaring emergency). For criticisms of the composition of the Emergency Committee, see Heath supra note 40, at 14-17.

${ }^{45}$ IHR, supra note 44, Art. 9 (the WHO "may take into account reports from sources other than notifications or consultations [with the source state]" and "then communicate [such] information on the event to the [source] state"; "[b]efore taking any action based on such reports, [to] consult with and attempt to obtain verification from the State Party in whose territory the event is allegedly occurring").

${ }^{46}$ Id. Art. 10; see also Art. 11. 
state any independent sources of information (unless "it is duly justified" in maintaining their confidentiality). This requirement naturally has a chilling effect on the potential contribution of whistleblowers. ${ }^{47}$

Moreover, the IHR limit the WHO's authority to issue travel advisories. The need to rely on Emergency Committees in response to outbreaks has turned into an invitation for political $^{48}$ and economic interests ${ }^{49}$ to intervene in expert decision making. Yet, the IHR do not fetter the discretion of states to adopt whatever trade-restricting measures they deem fit. ${ }^{50}$ This is reflected in Article 43 of the Regulations, which allows states parties to

implement[] health measures in accordance with their relevant national law and obligations under international law, in response to specific public health risks or public health emergencies of international concern, which: (a) achieve the same or greater level of health protection than WHO recommends; or ... are otherwise prohibited under [specific IHR provisions], provided such measures are otherwise consistent with these Regulations. ${ }^{51}$

The Article requires that those measures shall not be more restrictive, invasive, or intrusive "than reasonably available alternatives that would achieve the appropriate level of health protection." 52 But the WHO has no weight with which to sanction states taking such measures. Its only authority is to "request that the State Party concerned reconsider the application of the measures," if and when it complies with the duty to report such measures. ${ }^{53}$

In other words, the IHR both restricted the WHO's coordination function by limiting information and also undermined its cooperation-ensuring function by constraining the freedom of WHO leadership to act promptly vis-à-vis states' noncooperative behavior. The consequences of the IHR were laid bare in all subsequent pandemics. Two searching review processes set up by the WHO noted the institutional limitations. The IHR Review Committee established in the wake of the Swine Flu pandemic noted that " $t]$ he most important structural shortcoming of the IHR is the lack of enforceable sanctions," 54 and recommended (only) that the WHO try to shame states that adopt excessive measures. ${ }^{55}$ While the 2015 Report of the Ebola Interim Assessment Panel ${ }^{56}$ was ambitious, offering a universalist vision of "shared sovereignty" for interpreting the IHR as a vehicle for "international

\footnotetext{
${ }^{47}$ Id. Art. 9.

${ }^{48}$ According to IHR Article 48, a representative of the affected state must be involved.

${ }^{49}$ Abigail C. Deshman, Horizontal Review Between International Organizations: Why, How, and Who Cares About Corporate Regulatory Capture, 22 Eur. J. INT'L L. 1089 (2011).

${ }^{50}$ As Zacher and Keefe (supra note 34, at 69-70) rightly point out, the IHR "gave countries significant leeway in adopting more stringent measures. All that was required of states was that they discuss the more stringent measures that they intended to implement with WHO officials. In other words, states' sovereign rights of legislation have won out in the debate over excessive measures."

${ }^{51}$ IHR, supra note 44, Art. 43.

52 Id., sec. 4

${ }^{53} \mathrm{Id}$.

${ }^{54}$ WHO, Report of the Review Committee on the Functioning of the International Health Regulations (2005) in Relation to Pandemic (H1N1) 2009, para. 24, WHO Doc. A64/10 (May 5, 2011).

${ }^{55} \mathrm{Id}$.

56 WHO, Report of the Ebola Interim Assessment Panel (July 2015), at https://www.who.int/csr/resources/ publications/ebola/report-by-panel.pdf?ua $=1$.
} 
collective action and effective and efficient governance of the global health system," 57 the final Report of the Review Committee stopped short of suggesting reform. ${ }^{58}$

\section{Conclusion}

This analysis suggests that criticisms leveled at the WHO since the onset of the COVID-19 pandemic are fundamentally misguided. Undoubtedly, the organization failed to lead the world to "attain[] . . . the highest possible level of health." 59 But the failure lies with the member states who designed it. They created a body that is not equipped for the challenges it faces. International relations theorists assume that IOs are rationally designed to fit specific purposes. ${ }^{60}$ The discrepancy between the stated goals of the WHO and its design-whose flaws were built into the original (1948) concept and were later compounded in the adoption of the IHR (2005) — could either suggest that the assumption about rationality is misguided or that the WHO's designers tolerated the likelihood that it would fall short of its stated objective.

Thus far, member states have shown no political will to refit the WHO to meet its complex task of securing interstate cooperation. Will the various failures at the international and national levels to cope with the recent pandemic bring states closer to recognizing that the adoption of the concept of "shared sovereignty" is in their own long-term interests?

${ }^{57}$ Id. at 1, para. 9.

${ }^{58}$ WHO, Report of the Review Committee on the Role of the International Health Regulations (2005) in the Ebola Outbreak and Response, WHO Doc. A69/21 (May 13, 2016).

${ }^{59}$ WHO Constitution, supra note 21, Art.1.

${ }^{60}$ Koremenos, Lipson \& Snidal, supra note 13 , at 762. 